\title{
School Facilities and Infrastructure Management in Improving Education Quality
}

\author{
Felia Santika, Sowiyah, Umigiarini Pangestu and Mutiara Nurahlaini \\ Faculty of Teacher Training and Education, Universitas Lampung, Indonesia
}

\begin{abstract}
The purpose of this study is to know the Management of School Facilities and Infrastructure in Improving the Quality of Education. This study uses a comparison journal related to Facilities and Infrastructure in the field of education. Based on the results of a review of libraries from various countries in the world, the authors found that school facilities and infrastructure can improve the quality of education. Therefore, the school is expected to manage the facilities and pre-retirement in meeting the needs. Facilities and infrastructure greatly affect the ability of students in the learning process. It can be said that quality school facilities and infrastructure help attract and retain teachers, support improved student outcomes, and have a positive economic impact on the community. And it can be known that complete school facilities and infrastructure can determine the number of students. Therefore, the role of facilities and infrastructure is very important to attract the attention of the community so that the school has fans. The importance of school facilities and pre-retirement management in improving the quality of education attracts researchers to review, and this article to test how the management of facilities and infrastructure in improving the quality of education.
\end{abstract}

Keywords: education quality, education management, facilities and infrastructure management, literature review.

\section{INTRODUCTION}

$\mathrm{E}$ ducation is one of the basic needs for humans. Education can be one way for people to achieve their goals (Akareem \& Hossain, 2012). School as educational institution is basically established as a means for the teaching and learning process (Akhihiero, 2011). As the new demands on the education system, the education system is required to focus more on emphasizing the quality of education, especially on facilities and infrastructure. These shifts and changes occur not only in developed countries, but also in developing countries in the world. Educational facilities and infrastructure are supporting matters that facilitate the teaching and learning process in school. Facilities and infrastructure include school buildings, equipment including teaching aids, books, typewriters, computers and laboratory equipment (Akhihiero, 2011; Herwan, Aswandi, \& Chiar, 2018).

Facilities and infrastructure become one of the indicators of the quality of education because Facilities and Infrastructure in education is one of the determining factors in the success of education. The completeness of educational facilities and infrastructure in school greatly influences the effectiveness of learning, both in and out of the classroom (Darmastuti, 2014). However, in many schools in remote areas, the lack of facilities that support learning is still very often found (Vincent, 2006).

Related to this, there are several studies that have studied the impact of school facilities and infrastructure in improving the quality of education in various countries, such as in India (Bhunia, Shit, \& Dubai, 2012), Indonesia (Alkadri, Ningrum, Santoso, \& Afriansyah, 2017) (Darmastuti, 2014) (Marmoah, Adela, \& Fauziah, 2019) , South Africa (Amsterdam, 2013), Netherlands (Kok, Mobach, \& Omta, 2011), Kenya (Ndirangu \& Udoto, 2011), Bangladesh (Akareem \& Hossain, 2012), Cambodia (Chansopheak, 2009), Russia (Zhirnova \& Absalyamova, 2013), and United States (Wagner, 2010) (Murillo, Román, \& improvement, 2011).

Educational facilities are all forms of facilities or supportive learning stuffs, such as classrooms, learning media, tools, materials and others that are used to support the educational process at school. While infrastructure is all forms of things that work indirectly in supporting the teaching-learning process, because it includes land, yards, school buildings, roads to schools, sports fields, water, telephones, and furnitures (Herwan et al., 2018). Facilities and infrastructure greatly affect the ability of students in the learning process (Herwan et al., 2018). Good school facilities and infrastructure will attract and maintain teacher welfare, support the improvement of student outcomes, and have a positive economic impact on society. And it can be concluded that complete school facilities and infrastructure can determine the quantity of students (Vincent, 2012). Thus, the role of facilities and infrastructure is very important as a school attraction in the people's eyes (Alkadri et al., 2017).

The process of achieving educational goals needs to be supported by good quality resources, both human and material, and facilities and infrastructure is one of the material resources. Educational activities in schools that are not systematic often become a factor in the process of education. Every educational institution knows that the learning process in schools will never be static, but will always dynamically follow the progress of science and technology which is growing rapidly. For this reason, school is required to improve the quality of education from all sides, including improving the quality of educational facilities and infrastructure. Because school facilities and infrastructure is one of the supporting factors in achieving the success of the teaching and learning process in school. And this can be achieved if adequate school facilities and infrastructure are accompanied by optimal 
management (Nurbaiti, 2015). Based on the description above, it is necessary to know more deeply about "How is the school facilities and infrastructure management in improving the quality of education?".

\section{METHODOLOGY}

This research can be categorized as a literature review study. The purpose of the literature review is to get a theoretical foundation that can support in solving research problems. This literature review focuses on the management of school facilities and infrastructure in improving the quality of education. The review process begins by utilizing a search engine, Google Scholar, to search for articles with keywords: "School Facilities and Infrastructure Management and Education Quality". The article used is an article with a publication year from 2006-2020. The article criteria that will be used as literature in this study are as follows:

1) Qualitative and quantitative results from "school facilities and infrastructure management in improving the quality of education"

2) Research conducted in the world

3) This study uses English

4) Dissertations and theses are excluded
The steps in this Literature Review are:

Step 1: Formulate the ProblemChoose a topic that fits the issue and interestThe problem must be written completely

Step 2: Find Literature

- Find literature that is relevant to the research

- Get an overview of the research topic

- Research sources are very helpful if supported by knowledge of the topic.

- The articles provide an overview/summary of previous research.

Step 3: Data Evaluation

- Focus on articles' findings/contributions related to the topics discussed

- Find the right data source as needed to support research

- Data can be in the form of qualitative data, quantitative data or a combination of both

Step 4: Analysis and Interpretation

Discuss and find and summarize the literature

Table 1. School facilities and infrastructure management in improving the quality of education

\begin{tabular}{|c|c|c|c|c|c|}
\hline $\begin{array}{c}\text { Author and Year } \\
\text { of Publication }\end{array}$ & Title & Country & Methods & Sample & Findings \\
\hline $\begin{array}{l}\text { Noer Kamilatus } \\
\text { Sholihah (2019) }\end{array}$ & $\begin{array}{l}\text { Management of Education } \\
\text { Facilities and Infrastructure }\end{array}$ & Indonesia & Qualitative & ------- & $\begin{array}{l}\text { Based on research conducted at SMK Negeri } \\
\text { Mojokerto, it was found that adequate facilities } \\
\text { and infrastructure strongly supported the } \\
\text { educational process. }\end{array}$ \\
\hline $\begin{array}{lr}\text { Gouri } & \text { Sankar } \\
\text { Bhuni, } & \text { Pravat } \\
\text { Kumar } & \text { Shit \& } \\
\text { Soumen } & \text { Duary } \\
(2012) & \end{array}$ & $\begin{array}{l}\text { Assessment of School } \\
\text { Infrastructure at Primary and } \\
\text { Upper } \\
\text { Primary Level: A Geospatial } \\
\text { Analysis }\end{array}$ & India & Quantitative & 670 schools & $\begin{array}{l}\text { Based on this research, the use of the SSA system } \\
\text { to improve infrastructure shows that Geoinformat } \\
\text { technology is a powerful tool for assessing } \\
\text { infrastructure development zones, based on the } \\
\text { relevant decision-maker can formulate an } \\
\text { efficient basic infrastructure development plan for } \\
\text { the area that can be achieved. }\end{array}$ \\
\hline $\begin{array}{lr}\text { Sri } & \text { Marmoah, } \\
\text { Dhea } & \text { Adela, } \\
\text { Muna } & \text { Fauziah } \\
(2019) & \end{array}$ & $\begin{array}{l}\text { Implementation of facilities } \\
\text { and infrastructure } \\
\text { management in public } \\
\text { elementary schools }\end{array}$ & Indonesia & Qualitative & ------- & $\begin{array}{l}\text { Based on the results of research on the } \\
\text { implementation of management facilities and } \\
\text { infrastructure at Bakipandeyan Elementary } \\
\text { School, the school has implemented it well } \\
\text { through three stages: (1) Procurement of facilities } \\
\text { (2) Utilization and (3) Maintenance of facilities } \\
\text { and infrastructure. }\end{array}$ \\
\hline $\begin{array}{l}\text { Christina } \\
\text { Amsterdam } \\
(2013)\end{array}$ & $\begin{array}{l}\text { School Infrastructure in } \\
\text { South Africa: Views and } \\
\text { experiences } \\
\text { educators and learners }\end{array}$ & South Africa & Qualitative & ----- & $\begin{array}{l}\text { The results showed that educational facilities } \\
\text { have an important role in supporting the learning } \\
\text { process, the lack of facilities has a very negative } \\
\text { impact on the learning process. }\end{array}$ \\
\hline $\begin{array}{l}\text { Putut jatmiko } \\
\text { yuniawan, } \\
\text { wahyudi, \& } m \\
\text { chiar (2020) }\end{array}$ & $\begin{array}{l}\text { Manajemen sarana dan } \\
\text { prasarana untuk } \\
\text { meningkatkan mutu } \\
\text { pendidikan di smk negeri } 1 \\
\text { sintang } \\
\text { (Facilities and Infrastructure } \\
\text { Management to Improve the } \\
\text { Quality of Education in } \\
\text { SMK Negeri } 1 \text { Sintang) }\end{array}$ & Indonesia & Qualitative & -------- & $\begin{array}{l}\text { Based on the research findings, it can be } \\
\text { concluded that: (1) Planning of facility and } \\
\text { infrastructure programs is important for } \\
\text { developing the quality of activities in schools; } \\
\text { (2) The use of facilities and infrastructure must be } \\
\text { used in accordance with the learning needs of } \\
\text { each teacher that has been arranged and } \\
\text { monitored; } \\
\text { (3) Periodic monitoring and reporting of the use } \\
\text { of facilities and infrastructure has been carried } \\
\text { out directly by the school principal, } \\
\text { (5) Obstacles faced relating to facilities and } \\
\text { infrastructure include the costs of procurement } \\
\text { and maintenance. }\end{array}$ \\
\hline
\end{tabular}




\begin{tabular}{|c|c|c|c|c|c|}
\hline $\begin{array}{lr}\text { Herman B. } & \text { Kok, } \\
\& \quad \text { Mark } & \text { P. } \\
\text { Mobach, } & \text { Onno } \\
\text { S.W.F. } & \text { Omta } \\
(2011) & \end{array}$ & $\begin{array}{l}\text { The added value of facility } \\
\text { management in the } \\
\text { educational } \\
\text { environment }\end{array}$ & Netherlands & Qualitative & ------ & $\begin{array}{l}\text { The results of this study indicate that facility } \\
\text { services can directly influence the educational } \\
\text { process }\end{array}$ \\
\hline $\begin{array}{l}\text { Husain } \quad \text { Salilul } \\
\text { Akareem \& Syed } \\
\text { Shahadat } \text { Hossain } \\
\text { (2012) }\end{array}$ & $\begin{array}{l}\text { Perception of } r \text { education } \\
\text { quality in private } \\
\text { universities of Bangladesh: a } \\
\text { study from students' } \\
\text { perspective }\end{array}$ & Bangladesh & Quantitative & 400 & $\begin{array}{l}\text { Findings from research at Private Universities in } \\
\text { Bangladesh indicate that the quality of education } \\
\text { greatly influences the characteristics of students. } \\
\text { There is a strong correlation between the quality } \\
\text { of education and student characteristics. }\end{array}$ \\
\hline $\begin{array}{l}\text { Keng } \\
\text { Chansopheak } \\
\text { (2009) }\end{array}$ & $\begin{array}{l}\text { Basic Education } \\
\text { Cambodia: } \quad \text { Quality } \\
\text { Equity }\end{array}$ & Cambodia & Quantitative & $\begin{array}{l}8 \text { Elementary } \\
\text { schools in } \\
\text { Pursa and } 135 \\
\text { Schools in the } \\
\text { northeast of } \\
\text { Cambodia }\end{array}$ & $\begin{array}{l}\text { The results showed that the quality of education } \\
\text { has an important role on student achievement. } \\
\text { From this perspective, Cambodia's Elementary } \\
\text { School is currently in the low-quality category, } \\
\text { and student achievement is far from satisfying. }\end{array}$ \\
\hline $\begin{array}{ll}\text { Galina } & \text { I. } \\
\begin{array}{l}\text { Zhirnova, } \\
\text { \& } \frac{\text { Svetlana }}{\text { Absalyamova }}\end{array} \\
\frac{(2013)}{\text { G }}\end{array}$ & $\begin{array}{l}\text { Global innovation gap and } \\
\text { quality of education }\end{array}$ & Russia & Qualitative & ------- & $\begin{array}{l}\text { The results of this study indicate that the quality } \\
\text { of education as a determinant of development in } \\
\text { overcoming innovation and social inequalities. }\end{array}$ \\
\hline $\begin{array}{l}\text { Daniel } \\
\text { A. Wagner (2010) }\end{array}$ & $\begin{array}{l}\text { Quality of education, } \\
\text { comparability, and } \\
\text { assessment choice in } \\
\text { developing countries }\end{array}$ & $\begin{array}{l}\text { United } \\
\text { States }\end{array}$ & Qualitative & ------- & $\begin{array}{l}\text { The results showed that, most development } \\
\text { institutions have begun to emphasize improving } \\
\text { the quality of education. This review is paralleled } \\
\text { by a significant increase in the use of educational } \\
\text { quality assessments as a way to measure gains } \\
\text { and losses. }\end{array}$ \\
\hline $\begin{array}{l}\text { F. Javier Murillo a } \\
\text { \& Marcela Román } \\
\text { (2011) }\end{array}$ & $\begin{array}{l}\text { School infrastructure and } \\
\text { resources do matter: analysis } \\
\text { of the incidence of school } \\
\text { resources on the } \\
\text { performance of Latin } \\
\text { American students }\end{array}$ & $\begin{array}{l}\text { United } \\
\text { States }\end{array}$ & Quantitative & $\begin{array}{l}180.000 \text { Grade } \\
3 \text { and Grade } 6 \\
\text { students of } \\
\text { elementary } \\
\text { school from } \\
3.000 \text { schools } \\
\text { from } 15 \\
\text { countries }\end{array}$ & $\begin{array}{l}\text { Results show that the availability of basic } \\
\text { infrastructure and services (water, electricity, } \\
\text { sewage), didactic facilities (sport installations, } \\
\text { labs, libraries), as well as the number of books in } \\
\text { the library and computers in the school do have } \\
\text { an effect on the achievement of primary } \\
\text { education students in Latin America, but their } \\
\text { relative weight varies significantly from country } \\
\text { to country. }\end{array}$ \\
\hline $\begin{array}{l}\text { Ejiro Thelma } \\
\text { Akhihiero (2011) }\end{array}$ & $\begin{array}{l}\text { Effect of Inadequate } \\
\text { Infrastructural Facilities on } \\
\text { Academic Performance Of } \\
\text { Students Of Oredo Local } \\
\text { Government Area Of Edo } \\
\text { State }\end{array}$ & Nigeria & Qualitative & ---- & $\begin{array}{l}\text { The results of this study indicate that there is no } \\
\text { appropriate and effective education if there is no } \\
\text { provision of school facilities for effective } \\
\text { teaching and learning. Poor facilities and } \\
\text { infrastructure greatly affect the educational } \\
\text { process. }\end{array}$ \\
\hline $\begin{array}{l}\text { Hanif Alkadri, } \\
\text { Yulianto Santoso, } \\
\text { Tia Ayu Ningrum, } \\
\text { \&Hade } \\
\text { Afriansyah (2017) }\end{array}$ & $\begin{array}{l}\text { Essentiality of Management } \\
\text { of Facilities and } \\
\text { Infrastructure toward a } \\
\text { Number of Students of Early } \\
\text { Years Institution }\end{array}$ & Indonesia & Qualitative & ----- & $\begin{array}{l}\text { The results of this study indicate that facilities } \\
\text { and infrastructure are very important to attract } \\
\text { public interest. So, the condition of facilities and } \\
\text { infrastructure affects the quantity of students in } \\
\text { each year. }\end{array}$ \\
\hline $\begin{array}{l}\text { Hajeng } \\
\text { Darmastuti, } \\
\& \text { Karwanto } \\
(2014)\end{array}$ & $\begin{array}{l}\text { Manajemen Sarana Dan } \\
\text { Prasarana Dalam Upaya } \\
\text { Peningkatan Kualitas } \\
\text { Pembelajaran Pada Jurusan } \\
\text { Teknik Komputer Dan } \\
\text { Informatika Di Smk Negeri } \\
\text { 2 Surabaya } \\
\text { (Facilities and Infrastructure } \\
\text { Management in Improving } \\
\text { the Quality of Learning at } \\
\text { the Department of Computer } \\
\text { and Information } \\
\text { Engineering in SMK Negeri } \\
2 \text { Surabaya) }\end{array}$ & Indonesia & Qualitative & ----- & $\begin{array}{l}\text { The results of this study indicate that: (1) } \\
\text { Procurement and planning of facilities and } \\
\text { infrastructure in SMK Negeri } 2 \text { Surabaya aims to } \\
\text { find out all the school facilities and infrastructure } \\
\text { needs, planned since the beginning of the year by } \\
\text { looking at the results of the evaluation in the } \\
\text { previous year (2) Distribution of facilities and } \\
\text { infrastructure in SMK Negeri } 2 \text { Surabaya is by } \\
\text { selecting it as needed, then distributed to each } \\
\text { program department and class. (3) Utilization and } \\
\text { maintenance of facilities and infrastructure in } \\
\text { SMK Negeri } 2 \text { Surabaya adjusted to the needs of } \\
\text { teachers and students, there are rules that must be } \\
\text { obeyed, submitted to each program department } \\
\text { and class. (4) There is a special staff in charge of } \\
\text { recording the utilization of facilities and } \\
\text { infrastructure inventory in SMK Negeri } 2 \\
\text { Surabaya. (5) The method of eliminating } \\
\text { (Stopping the use of) facilities and infrastructure } \\
\text { in SMK Negeri } 2 \text { Surabaya is to make an official } \\
\text { report to the principal, and can only be made if } \\
\text { the facilities and infrastructure have been }\end{array}$ \\
\hline
\end{tabular}




\begin{tabular}{|c|c|c|c|c|c|}
\hline & & & & & $\begin{array}{l}\text { damaged. (6) Efforts to improve the quality of } \\
\text { facilities and infrastructure in SMK Negeri } 2 \\
\text { Surabaya include having good and skilled } \\
\text { administrative staff and also support from school } \\
\text { residents. }\end{array}$ \\
\hline $\begin{array}{l}\text { Herwan, Aswandi, } \\
\text { \&M.Chiar (2018) }\end{array}$ & $\begin{array}{l}\text { The Role of School } \\
\text { Committee in Supporting } \\
\text { the Fulfillment of Education } \\
\text { Facilities and Infrastructure }\end{array}$ & Indonesia & Qualitative & ------ & $\begin{array}{l}\text { Based on the findings of this study, it can be } \\
\text { concluded that: } \\
1 \text {. The committee of SMKN } 1 \text { Teluk Keramat has } \\
\text { done their role as an advisor, as a supporting } \\
\text { agent, as a controlling agent, and as a mediator } \\
\text { agent. } \\
2 \text {. One of the supporting factors in improving the } \\
\text { quality of facilities and infrastructure in SMKN } 1 \\
\text { Teluk Keramat is that the school committee is } \\
\text { very supportive in fulfilling educational facilities } \\
\text { and infrastructure. }\end{array}$ \\
\hline $\begin{array}{l}\text { Miftakhul Jannah } \\
\text { (2010) }\end{array}$ & $\begin{array}{l}\text { Optimalisasi Manajemen } \\
\text { Sarana Dan Prasarana } \\
\text { Dalam Meningkatkan Mutu } \\
\text { Pembelajaran Di Smp } \\
\text { Nasima Semarang } \\
\text { (Optimization of Facilities } \\
\text { and Infrastructure } \\
\text { Management in Improving } \\
\text { the Quality of Learning in } \\
\text { SMP Nasima Semarang) }\end{array}$ & Indonesia & Qualitative & --------- & $\begin{array}{l}\text { The results showed that the implementation of } \\
\text { facilities and infrastructure management at SMP } \\
\text { Nasima included: planning, procurement, } \\
\text { inventory, storage, structuring, utilization, } \\
\text { maintenance, and stopping use if the facility was } \\
\text { damaged. }\end{array}$ \\
\hline $\begin{array}{lr}\text { Mwangi } & \\
\text { Ndirangu, } & \& \\
\text { Maurice } & \text { O. } \\
\text { Udoto( 2011) } & \end{array}$ & $\begin{array}{l}\text { Quality of learning facilities } \\
\text { and learning environment } \\
\text { Challenges for teaching and } \\
\text { learning in Kenya's public } \\
\text { universities }\end{array}$ & Kenya & Quantitative & $\begin{array}{l}600 \quad \text { Higher } \\
\text { Education } \\
\text { Students, } 120 \\
\text { Academic } \\
\text { Staffs }\end{array}$ & $\begin{array}{l}\text { The findings of this study indicate the quality of } \\
\text { libraries, resources, and lecture facilities provided } \\
\text { by Kenya State University do not meet quality } \\
\text { standards. They cannot support educational } \\
\text { programs effectively and cannot facilitate the } \\
\text { development of a learning environment that } \\
\text { supports students and lecturers to achieve their } \\
\text { goals. }\end{array}$ \\
\hline Nurbaiti (2015) & $\begin{array}{l}\text { School Facilities and } \\
\text { Infrastructure Management }\end{array}$ & Indonesia & Qualitative & $\begin{array}{l}\text { Principals and } \\
\text { teachers }\end{array}$ & $\begin{array}{l}\text { This research shows that the planning and } \\
\text { procurement of facilities and infrastructure by the } \\
\text { school principal has fulfilled the provisions } \\
\text { (criteria), inventory of school facilities and } \\
\text { infrastructure has been done well, direct and } \\
\text { indirect distribution, periodic maintenance of } \\
\text { school facilities and infrastructure, supervision } \\
\text { and accountability (reporting) school facilities } \\
\text { and infrastructure by the school principal are } \\
\text { conducted once a year during the new school } \\
\text { year. }\end{array}$ \\
\hline $\begin{array}{l}\text { Reza Pahlevi, Ali } \\
\text { Imron, \&Desi Eri } \\
\text { Kusumaningrum } \\
(2016)\end{array}$ & $\begin{array}{l}\text { Manajemen sarana dan } \\
\text { prasarana untuk } \\
\text { meningkatkan mutu } \\
\text { pembelajaran } \\
\text { (Facilities and infrastructure } \\
\text { management to improve the } \\
\text { quality of learning) }\end{array}$ & Indonesia & Qualitative & ------- & $\begin{array}{l}\text { The results of this study indicate that the planning } \\
\text { of facilities and infrastructure at this school is } \\
\text { carried out by staff of the Deputy Head of } \\
\text { Facilities and Infrastructure. }\end{array}$ \\
\hline $\begin{array}{l}\frac{\text { Halina }}{\text { Pratasavitskaya, } \&} \\
\frac{\text { BjØrn Stensaker }}{(2010)}\end{array}$ & $\begin{array}{l}\text { Quality Management in } \\
\text { Higher Education: Towards } \\
\text { a Better Understanding of an } \\
\text { Emerging Field }\end{array}$ & Norway & Qualitative & --------- & $\begin{array}{l}\text { The results show that research in the field of } \\
\text { quality management can be studied in a } \\
\text { heterogeneous conceptual and multidisciplinary } \\
\text { manner. }\end{array}$ \\
\hline Purwadhi (2019) & $\begin{array}{l}\text { The role of education } \\
\text { management, learning } \\
\text { teaching and institutional } \\
\text { climate on quality of } \\
\text { education: Evidence from } \\
\text { Indonesia }\end{array}$ & Indonesia & Quantitative & $\begin{array}{l}268 \\
\text { Respondents }\end{array}$ & $\begin{array}{l}\text { The findings of this study indicate that } \\
\text { educational learning and leadership management, } \\
\text { learning teaching and school climate influence on } \\
\text { quality of education, has a very positive influence }\end{array}$ \\
\hline
\end{tabular}

\section{DISCUSSION OF FINDINGS}

This section reports the key findings reviewed from some articles that the author has read. The analysis showed that most articles focus on how the School Facilities and
Infrastructure in Improving the Quality of Education. The articles that have been reviewed are research conducted in the world. Based on the articles that are reviewed, there are various ways of data collection related to the School Facilities 
and Infrastructure. The most commonly used method is using quantitative and qualitative methods.

Research on the school facilities and infrastructure management in improving the quality of education has been studied in many countries. Table 1 shows that research on this topic has been studied in many schools and universities in the world. The purpose of this article is to find out the management of school facilities and infrastructure in improving the quality of education. Considering the importance of research on the management of school facilities and infrastructure in improving the quality of education but very rarely research that explores the relationship of these studies, so the findings of this study are worthy of attention. The importance of understanding the management of school facilities and infrastructure in improving the quality of education requires further discussion.

Based on the results of the research from Table 1, most of it shows that the management of school facilities and infrastructure has a very strong impact in improving the quality of education and in supporting the educational process. These results are reinforced by Alkadri et.al in his research which stated that "The results of the study indicate that facilities and infrastructure are very important to attract public interest, so, the condition of facilities and infrastructure affects the quantity of students in each year" (Alkadri et al., 2017). Christina Amsterdam Research says that "Educational facilities have an important role in supporting the learning process" (Amsterdam, 2010). Ejiro Thelma Akhihiero also stated that "No appropriate and effective education will happen if there is no provision of school facilities for effective teaching and learning" (Akhihiero, 2011). Noer Kamilatus Sholihah's research results stated that "Adequate facilities and infrastructure can greatly support the educational process" (Sholihah, 2019). The results from Chansopheak's research show that "Quality has an important role in student achievement and to improve the quality of education" (Chansopheak, 2009). The results of the study by Daniel A Wagner show that bahwa "The results showed that, most development institutions have begun to emphasize improving the quality of education. This review is paralleled by a significant increase in the use of educational quality assessments as a way to measure gains and losses"(Wagner, 2010). Therefore, it can be stated that the results of the school facilities and infrastructure management in improving the quality of education have an impact in supporting the education process and have an important role in improving the quality of education.

Based on the results of the literature review, considering all studies reviewed on school facilities and infrastructure management in improving the quality of education from various countries in the world, researchers can make general conclusions that there is a significant relationship between school facilities and infrastructure management and the quality of education. School facilities and infrastructure management has an impact in supporting the education process and has an important role in improving the quality of education.

As research in general, this literature review also has limitations, some of those limitations are: First, the articles reviewed are only articles written in English, so, other studies written in other languages are not reviewed due to language limitations. Second, dissertations and theses are not discussed in this article because they can cause publication bias in the results. Third, the scopes of the articles reviewed are still very limited, and it is very difficult to get literature that combines these two variables.

Despite the limitations of the literature that we must admit, our findings are expected to contribute information on he management of school facilities and infrastructure in improving the quality of education by looking at previous research in the context of the world. In addition, it can help to develop the process of managing school facilities and infrastructure effectively and efficiently. Thus, it can expand the view of all of us in developing school facilities and preretirement. So it is expected that with the management of school facilities and infrastructure is able to improve the quality of education.

\section{REFERENCES}

[1] Akareem, H. S., \& Hossain, S. S. (2012). Perception of education quality in private universities of Bangladesh: a study from students' perspective. 22(1), 11-33. doi:10.1080/08841241.2012.705792

[2] Akhihiero, E. T. (2011). Effect of inadequate infrastructural facilities on academic performance of students Of Oredo Local Government Area of Edo State. Paper presented at the The Nigerian Academic Forum.

[3] Alkadri, H., Ningrum, T. A., Santoso, Y., \& Afriansyah, H. (2017). Essentiality of Management of Facilities and Infrastructure toward a Number of Students of Early Years Institution. Paper presented at the International Conference of Early Childhood Education (ICECE 2017).

[4] Amsterdam, C. (2010). School Infrastructure in South Africa: Views and experiences of educators and learners. Paper presented at the Conference Paper: International Conference on Education.

[5] Amsterdam, C. (2013). School Infrastructure in South Africa: Views and experiences of educators and learners. In.

[6] Bhunia, G. S., Shit, P. K., \& Dubai, S. (2012). Assessment of school infrastructure at primary and upper primary level: A geospatial analysis. Journal of Geographic Information System, 4(05), 412. doi:10.4236/jgis.2012.45047

[7] Chansopheak, K. (2009). Basic education in Cambodia: Quality and equity. In The political economy of educational reforms and capacity development in Southeast Asia (pp. 131-152): Springer.

[8] Darmastuti, H. (2014). Manajemen Sarana dan Prasarana dalam Upaya Peningkatan Kualitas Pembelajaran pada Jurusan Teknik Komputer dan Informatika di SMK Negeri 2 Surabaya. Inspirasi Manajemen Pendidikan, 3(3).

[9] Herwan, H., Aswandi, A., \& Chiar, M. (2018). The Role of School Committee in Supporting The Fulfillment of Education Facilities and Infrastructure. Journal of Education, Teaching and Learning, $3(2), 282-287$.

[10] Jannah, M. (2010). Optimalisasi manajemen sarana dan prasarana dalam meningkatkan mutu pembelajaran di SMP Nasima Semarang. IAIN Walisongo, Retrieved from http://eprints.walisongo.ac.id/id/eprint/4716 
[11] Jannah, S. R. (2013). Karakteristik Dan Spektrum Manajemen Pendidikan Islam. Al-Fikrah: Jurnal Kependidikan Islam IAIN Sulthan Thaha Saifuddin, 4.

[12] Kok, H. B., Mobach, M. P., \& Omta, O. S. (2011). The added value of facility management in the educational environment. Journal of Facilities Management, 9(4), 249-265. doi:10.1108/14725961111170662

[13] Kumar, K. J. C. E. D. (2010). Quality in education: Competing concepts. 7(1), 7-18. doi:10.1177/0973184913411197

[14] Marmoah, S., Adela, D., \& Fauziah, m. (2019). Implementation of facilities and infrastructure management in public elementary schools. Al-Tanzim: Jurnal Manajemen Pendidikan Islam, 3(1), 102-134. doi:10.33650/al-tanzim.v3i1.507

[15] Mokoginta, H. E. (2012). Implementasi Manajemen Mutu Terpadu Dalam Peningkatan Kualitas Pendidikan Tinggi. Prosiding APTEKINDO, 6(1).

[16] Murillo, F. J., Román, M. J. S. e., \& improvement, s. (2011) School infrastructure and resources do matter: analysis of the incidence of school resources on the performance of Latin $\begin{array}{lll}\text { American } & \text { students. } & \text { 22(1), }\end{array}$ doi: $10.1080 / 09243453.2010 .543538$

[17] Ndirangu, M., \& Udoto, M. O. (2011). Quality of learning facilities and learning environment: Challenges for teaching and learning in Kenya's public universities. Quality Assurance in Education, 19(3), 208-223. doi:10.1108/09684881111158036

[18] Nurbaiti, N. (2015). Manajemen Sarana dan Prasarana Sekolah. Manajer Pendidikan, 9(4).

[19] Pahlevi, R., Imron, A., \& Kusumaningrum, D. E. (2016). Manajemen saranan dan prasarana untuk meningkatkan mutu penbelajaran. Manajemen Pendidikan, 25(1), 88-94.
[20] Pratasavitskaya, H., \& Stensaker, B. r. (2010). Quality management in higher education: towards a better understanding of an emerging field. Quality in Higher Education, 16(1), 37-50. doi:10.1080/13538321003679465

[21] Purwadhi, M. J. M. S. L. (2019). The role of education management, learning teaching and institutional climate on quality of education: evidence from Indonesia. 9(9), 1507-1518. doi: 10.5267/j.msl.2019.5.002

[22] Sholihah, N. K. (2019). Management of Education Facilities and Infrastructure. Paper presented at the 3rd International Conference on Education Innovation (ICEI 2019).

[23] Vincent, J. M. (2006). Public schools as public infrastructure: Roles for planning researchers. Journal of Planning Education and Research, 25(4), 433-437. doi:10.1177/0739456X06288092

[24] Vincent, J. M. (2012). California's K-12 educational infrastructure investments: Leveraging the state's role for quality school facilities in sustainable communities.

[25] Wagner, D. A. J. (2010). Quality of education, comparability, and assessment choice in developing countries. 40(6), 741-760. doi: 10.1080/03057925.2010.523231

[26] Yuniawan, P. J., Wahyudi, \& Chiar, M. (2020). Manajemen Sarana dan Prasarana untuk Meningkatkan Mutu Pendidikan di Smk NegeriI 1 Sintang. Jurnal Pendidikan dan Pembelajaran Khatulistiwa, 9(1).

[27] Zhirnova, G. I., \& Absalyamova, S. G. (2013). Global innovation gap and quality of education. Paper presented at the 2013 International Conference on Interactive Collaborative Learning (ICL). 